\title{
Influence of lifestyle on the course of type 1 diabetes mellitus
}

\author{
Stanisław Piłaciński, Dorota A. Zozulińska-Ziółkiewicz
}

Department of Internal Medicine and Diabetology, Poznan University of Medical Sciences, Poland

Submitted: 7 January 2013

Accepted: 2 June 2013

Arch Med Sci 2014; 10, 1: 124-134

DOI: 10.5114/aoms.2014.40739

Copyright $\odot 2014$ Termedia \& Banach

\section{Abstract}

Type 1 diabetes (T1DM) is an autoimmune disease that requires insulin treatment from the time of diagnosis. Its clinical course depends on both genetic and environmental factors, and the lifestyle of a patient modulates their interaction. The evidence about the influence of lifestyle on the course of T1DM is increasing. In this paper, we present evidence on the relationship between lifestyle parameters and diabetes-related outcomes. We discuss the most commonly addressed factors associated with lifestyle, such as physical activity, nutrition and smoking, and those with sparse evidence in T1DM, such as socioeconomic status, sleep duration, psychological stress and illicit drugs intake.

Key words: physical activity, nutrition, smoking, stress, socioeconomic conditions.

\section{Clinical course of type 1 diabetes}

Since the first therapeutic use of insulin the clinical course of type 1 diabetes (T1DM) has changed dramatically from a disease with very short life expectancy to a chronic condition, the course of which is influenced largely by the development of chronic complications.

The clinical onset of T1DM is preceded by a preclinical phase of variable duration, characterized by progressive autoimmune destruction of beta cells and presence of specific autoantibodies. In genetically susceptible individuals, this autoimmune reaction seems to be initiated and modulated by exposure to various environmental triggers and regulators, which might include viral infections or introducing cow's milk or cereals into the diet [1]. According to the accelerator hypothesis [2], an increased rate of $\beta$-cell apoptosis and insulin resistance modulate the timing of clinical onset and subsequent course of autoimmune diabetes. However, the autoimmune process is thought to be the main accelerator of $\beta$-cell destruction both before and after onset of T1DM [3].

Clinical manifestation of T1DM varies considerably in severity with greater insulin deficiency and greater risk of diabetic ketoacidosis (DKA) in children and adolescents than in adults [4]. After introduction of insulin treatment, many patients enter clinical remission of the disease with partially restored endogenous insulin secretion and near-normoglycemia on very low doses of exogenous insulin. In many patients with phenotypic

\author{
Corresponding author: \\ Stanisław Piłaciński MD, PhD \\ Department of Internal \\ Medicine \\ and Diabetology \\ Poznan University \\ of Medical Sciences \\ 2 Mickiewicza St \\ 60-834 Poznan, Poland \\ Phone: +48 618474579 \\ Fax: +48 618474579 \\ E-mail: pilacins@ump.edu.pl
}


T1DM residual insulin secretion can be maintained for over 30 years, and is associated with better metabolic control, including decreased incidence of both hyper- and hypoglycemia, and decreased risk of chronic complications when compared with patients without detectable insulin secretion [5]. In the DCCT/EDIC (Diabetes Control and Complications Trial/ Epidemiology of Diabetes Interventions and Complications) cohort, good initial metabolic control had a protective effect against chronic complications even despite subsequent deterioration in glycemic control [6]. Chronic complications of T1DM typically do not occur before 5 years from the disease onset, with the highest risk of their early development in patients with diabetes diagnosed in puberty. Progression of microvascular complications leads to decreased quality of life and increased risk of macrovascular disease [7]. Cardiovascular complications are the main cause of death in patients with T1DM. In the FinnDiane study, the 7-year mortality in patients with T1DM was three times higher than in the general population, although the difference disappeared after excluding patients with nephropathy [8].

To describe quantitatively the efficacy of interventions on the course of diabetes many endpoints are used. The hard endpoints include: time of the disease onset (in prevention trials), onset and progression of microvascular complications (e.g. development of end-stage renal failure or proliferative retinopathy), acute hyperglycemic states, episodes of hypoglycemia, cardiovascular events, and mortality. The surrogate endpoints and other commonly used outcomes that characterize the course of diabetes may include: parameters of metabolic control, occurrence and duration of clinical remission, measures of residual insulin secretion, exogenous insulin dose, insulin sensitivity, and quality of life.

The clinical course of T1DM depends on a number of factors, including genetic background [9], metabolic control (control of glycemia, lipid profile, blood pressure, body weight), treatment regimen used, physical activity, patient knowledge about diabetes, psychosocial factors and concomitant diseases. It is clear that many of these factors interact with lifestyle, and the lifestyle of a patient may in many ways influence the clinical course of T1DM.

To prepare this narrative review we searched the PubMed database using keywords describing lifestyle parameters (lifestyle, nutrition, diet, exercise, training, sport, physical activity, fitness, smoking, sleep, stress, socioeconomic, income, education) and diabetes-related outcomes (mortality, complications, cardiovascular, macroangiopathy, microangiopathy, retinopathy, nephropathy, neuropathy, glyc(a)emic control, glycated hemo- globin $\left(\mathrm{HbA}_{1 \mathrm{c}}\right)$, glycated $\mathrm{h}(\mathrm{a})$ emoglobin, lipid profile, cholesterol, triglyceride, blood pressure, remission, insulin secretion, insulin requirement, insulin dose, insulin resistance). We confined the search to papers where patients with T1DM (searched also using the keyword insulin-dependent diabetes mellitus) were the only investigated group or one of the subgroups with separately presented outcomes. Papers where the type of diabetes was not specified were excluded. The studies conducted in patients with T1DM which are discussed in this review are summarized in Table I.

\section{Definition of lifestyle}

Lifestyle is defined (according to the Thesaurus of Psychological Index Terms [10]) as a "typical way of life or manner of living characteristic of an individual or group" and is influenced by socioeconomic, educational, and cultural factors. The lifestyle is closely related with the health behavior, defined as behaviors expressed by individuals to protect, maintain or promote their health status. In the World Health Organization's Health Promotion Glossary [11] the lifestyle is defined as a "way of living based on identifiable patterns of behaviour which are determined by the interplay between an individual's personal characteristics, social interactions, and socioeconomic and environmental living conditions". The parameters most commonly analyzed in the assessment of lifestyle interventions include physical activity and nutrition. Other parameters that were taken into account include socioeconomic level, exposure to emotional stress, sleep duration, and specific unhealthy behaviors, including smoking, excessive alcohol intake and illicit drug use.

In the influence of a patient's lifestyle on the course of T1DM there is an important role for an appropriate treatment regimen. For the majority of patients with T1DM, the treatment of choice is intensive insulin therapy with pen injections or personal pumps, with dose adjustment based on glycemia, macronutrient (at least carbohydrate) content of the meals and planned physical activity. In the DCCT/EDIC cohort, intensive insulin treatment was effective in the prevention of chronic complications of diabetes [12]. Allowing high flexibility in dietary choices and meal planning, as well as safe practice of physical activity, the flexible intensive insulin treatment interferes little with a patient's lifestyle and has the potential of achieving the best possible outcome.

\section{Physical activity}

The beneficial effects of physical activity in the general population are numerous and include, apart from enhancement of well-being, decreased 
Table I. Lifestyle parameters and diabetes-related outcomes. Summary of reviewed studies

\begin{tabular}{|c|c|c|c|c|c|}
\hline Ref. & $\begin{array}{l}\text { First author, } \\
\text { publication date }\end{array}$ & $\begin{array}{l}\text { Intervention or } \\
\text { exposure }\end{array}$ & Study design & $\begin{array}{l}N \text { (cases/ } \\
\text { controls) }\end{array}$ & Main outcome(s) \\
\hline [15] & Moy, 1993 & $\begin{array}{l}\text { Overall physical } \\
\text { activity level }\end{array}$ & $\mathrm{OP}$ & 548 & Mortality \\
\hline [18] & Zinman, 1984 & $\begin{array}{l}\text { Aerobic } \\
\text { exercise }\end{array}$ & $\mathrm{CT}$ & $13 / 7$ & Glycemia, $\mathrm{HbA}_{1 \mathrm{c}}$ \\
\hline [19] & Durak, 1990 & $\begin{array}{l}\text { Progressive } \\
\text { resistance } \\
\text { training }\end{array}$ & $\mathrm{RCT}$, crossover & 8 & $\mathrm{HbA}_{1 \mathrm{c}}$, lipid profile, muscle strength \\
\hline [20] & Laaksonen, 2000 & $\begin{array}{l}\text { Aerobic } \\
\text { exercise }\end{array}$ & $\mathrm{RCT}$ & $28 / 28$ & Lipid profile \\
\hline [21] & Tonoli, 2012 & $\begin{array}{l}\text { Aerobic and/ } \\
\text { or resistance } \\
\text { training }\end{array}$ & Meta-analysis & 33 studies $^{1}$ & $\mathrm{HbA}_{1 \mathrm{c}}$, glycemia \\
\hline [25] & Rigla, 2000 & $\begin{array}{l}\text { Aerobic and } \\
\text { resistance } \\
\text { training }\end{array}$ & Self-controlled & 14 & Lipid profile, $\mathrm{BMI}, \mathrm{VO}_{2} \max$ \\
\hline [26] & Mosher, 1998 & $\begin{array}{l}\text { Aerobic } \\
\text { exercise }\end{array}$ & $\mathrm{CT}$ & $10 / 10$ & $\begin{array}{l}\mathrm{HbA}_{1 \mathrm{c}} \text {, fasting glycemia, lipid } \\
\text { profile, muscle strength }\end{array}$ \\
\hline$[27]$ & Kaplan, 1997 & $\begin{array}{l}\text { Aerobic } \\
\text { exercise }\end{array}$ & Self-controlled & 20 & Lipid profile, $\mathrm{BP}$, body fat, $\mathrm{VO}_{2} \max$ \\
\hline [29] & LaPorte, 1986 & $\begin{array}{l}\text { Various types } \\
\text { of exercise }\end{array}$ & Case-control & 696 & $\begin{array}{l}\text { Chronic complications of diabetes, } \\
\text { mortality }\end{array}$ \\
\hline [31] & Chen, 2008 & $\begin{array}{l}\text { Various types } \\
\text { of exercise }\end{array}$ & C-S & $93 / 107$ & Heart-rate variability \\
\hline [33] & Yki-Jarvinen, 1984 & $\begin{array}{l}\text { Aerobic } \\
\text { exercise }\end{array}$ & $\mathrm{CT}$ & $7 / 6$ & $\begin{array}{l}\text { Glucose disposal rate, insulin } \\
\text { requirement, } \mathrm{HbA}_{1 \mathrm{c}} \text {, lipid profile }\end{array}$ \\
\hline [36] & Seeger, 2011 & $\begin{array}{l}\text { Aerobic } \\
\text { exercise }\end{array}$ & Self-controlled & 7 & $\begin{array}{c}\text { Vascular function } \\
\text { (flow-mediated dilation) }\end{array}$ \\
\hline [37] & $\begin{array}{l}\text { Fuchsjager-Mayrl, } \\
\qquad 2002\end{array}$ & $\begin{array}{l}\text { Aerobic } \\
\text { exercise }\end{array}$ & $\mathrm{CT}$ & $18 / 8$ & $\begin{array}{c}\text { Vascular function } \\
\text { (flow-mediated dilation, } \\
\text { fundus pulsation amplitude) }\end{array}$ \\
\hline$[40]$ & Zoppini, 2003 & $\begin{array}{l}\text { Various types } \\
\text { of exercise }\end{array}$ & C-S & $30 / 23$ & Quality of life \\
\hline [48] & Buyken, 2001 & $\begin{array}{l}\text { Glycemic index } \\
\text { of diet }\end{array}$ & C-S & 2810 & $\mathrm{HbA}_{1 c}$, lipid profile \\
\hline [49] & Bortsov, 2011 & $\begin{array}{c}\text { Sugar- } \\
\text { sweetened and } \\
\text { diet beverage } \\
\text { intake }\end{array}$ & C-S & 1806 & $\mathrm{HbA}_{1 \mathrm{c}}$, lipid profile \\
\hline$[50]$ & Nansel, 2012 & $\begin{array}{l}\text { Diet quality } \\
\text { and glycemic } \\
\text { index }\end{array}$ & C-S & 252 & $\mathrm{HbA}_{1 \mathrm{c}}, \mathrm{BMI}$ \\
\hline [52] & Delahanty, 2009 & $\begin{array}{l}\text { Macronutrient } \\
\text { composition }\end{array}$ & $\mathrm{RCT}$ & 532 & $\mathrm{HbA}_{1 \mathrm{c}}$, lipid profile, $\mathrm{BMI}$ \\
\hline [53] & $\begin{array}{l}\text { Snell-Bergeon, } \\
2009\end{array}$ & $\begin{array}{l}\text { Macronutrient } \\
\text { composition }\end{array}$ & C-S & $571 / 696$ & $\begin{array}{c}\text { Coronary artery calcium, coronary } \\
\text { heart disease risk factors }\end{array}$ \\
\hline [55] & Strychar, 2009 & $\begin{array}{l}\text { Macronutrient } \\
\text { composition }\end{array}$ & $\mathrm{RCT}$ & $30(15 / 15)$ & $\begin{array}{l}\mathrm{BMI}, \mathrm{BP}, \mathrm{HbA}_{1 \mathrm{c}} \text {, lipid profile, serum } \\
\text { plasminogen activator inhibitor-1 }\end{array}$ \\
\hline$[60]$ & Matheus, 2011 & $\begin{array}{l}\text { Serum uric acid } \\
\text { concentration }\end{array}$ & C-S & $57 / 53$ & $\begin{array}{c}\text { Microvascular endothelial function } \\
\text { (laser Doppler } \\
\text { perfusion monitoring) }\end{array}$ \\
\hline [73] & Moy, 1990 & $\begin{array}{l}\text { Cigarette } \\
\text { smoking }\end{array}$ & $\mathrm{OP}$ & 548 & Mortality \\
\hline$[74]$ & Chiodera, 1997 & $\begin{array}{l}\text { Cigarette } \\
\text { smoking }\end{array}$ & $\mathrm{CT}$ & $10 / 10$ & $\begin{array}{l}\text { Growth hormone, vasopressin, } \\
\text { and cortisol concentrations }\end{array}$ \\
\hline
\end{tabular}


Table I. Continued

\begin{tabular}{|c|c|c|c|c|c|}
\hline Ref. & $\begin{array}{l}\text { First author, } \\
\text { publication date }\end{array}$ & $\begin{array}{l}\text { Intervention or } \\
\text { exposure }\end{array}$ & Study design & $\begin{array}{l}N \text { (cases/ } \\
\text { controls) }\end{array}$ & Main outcome(s) \\
\hline [78] & Pilacinski, 2012 & $\begin{array}{l}\text { Cigarette } \\
\text { smoking }\end{array}$ & OP & 149 & Duration of partial remission, $\mathrm{HbA}_{1 \mathrm{c}}$ \\
\hline [79] & Haire-Joshu, 1994 & $\begin{array}{l}\text { Cigarette } \\
\text { smoking }\end{array}$ & C-S & $\begin{array}{c}186 \\
(83 / 103)\end{array}$ & Symptoms of depression \\
\hline [81] & Sawicki, 1994 & $\begin{array}{l}\text { Cigarette } \\
\text { smoking }\end{array}$ & OP & 93 & $\begin{array}{l}\text { Progression of diabetic } \\
\text { nephropathy }\end{array}$ \\
\hline [82] & Muhlhauser, 1996 & $\begin{array}{l}\text { Cigarette } \\
\text { smoking }\end{array}$ & OP & 636 & $\begin{array}{l}\text { Onset or progression of diabetic } \\
\text { retinopathy or nephropathy }\end{array}$ \\
\hline [83] & Mitchell, 1990 & $\begin{array}{l}\text { Cigarette } \\
\text { smoking }\end{array}$ & Case-control & 163 & Prevalence of diabetic neuropathy \\
\hline [86] & Lloyd, 1999 & $\begin{array}{l}\text { Stressful life } \\
\text { events }\end{array}$ & Case-control & 55 & $\mathrm{HbA}_{1 \mathrm{c}}$ \\
\hline [87] & Wiesli, 2005 & $\begin{array}{c}\text { Psychological } \\
\text { stress - Trier } \\
\text { Social Stress } \\
\text { Test (TSST) }\end{array}$ & CT & 40 & Glycemia \\
\hline [88] & Riazi, 2004 & Daily stress & OP & 54 & Glycemia, $\mathrm{HbA}_{1 c}$ \\
\hline [91] & Donga, 2010 & $\begin{array}{l}\text { Sleep } \\
\text { restriction }\end{array}$ & Self-controlled & 7 & Glucose disposal rate \\
\hline [92] & Borel, 2009 & Sleep duration & C-S & 20 & Blood pressure dipping status \\
\hline [93] & van Dijk, 2011 & Sleep quality & C-S & 99 & $\mathrm{HbA}_{1 c^{\prime}}$ symptoms of depression \\
\hline [94] & Perfect, 2012 & $\begin{array}{c}\text { Sleep } \\
\text { architecture }\end{array}$ & $\begin{array}{l}\text { CT (external } \\
\text { controls) }\end{array}$ & $40 / 40$ & $\mathrm{HbA}_{1 c}$, glycemia, QOL \\
\hline [95] & Secrest, 2011 & $\begin{array}{l}\text { Socioeconomic } \\
\text { status }\end{array}$ & OP & 317 & Chronic complications of diabetes \\
\hline [97] & Zgibor, 2000 & $\begin{array}{c}\text { General/ } \\
\text { specialist care, } \\
\text { education level, } \\
\text { income }\end{array}$ & $\mathrm{OP}$ & 429 & $\mathrm{HbA}_{1 \mathrm{c}}$ \\
\hline
\end{tabular}

Ref. - reference number, RCT - randomized controlled trial, CT - controlled trial (not randomized), OP - prospective observational study,

C-S - cross-sectional study; 'number of studies varied between analyses (studies with different types of exercises were analyzed separately)

risk of cardiovascular and all-cause mortality, hypertension, obesity, dyslipidemia, type 2 diabetes (T2DM), osteoporosis, and cancer [13]. Some of these effects were also documented in patients with T2DM, but the body of evidence for T1DM is limited [14]. Therefore, many recommendations on physical activity for patients with T1DM are based on conclusions driven from studies on patients with T2DM or on healthy individuals.

Patients with T1DM undertake lower than advised levels of physical activity, but these levels are similar to nondiabetic subjects [15]. The sedentary lifestyle and increased time spent watching television or using a computer was associated with poor glycemic control in young patients with T1DM [16]. However, the beneficial impact of physical activity on glycemic control of T1DM is less documented than for patients with T2DM [17]. Some studies have demonstrated the improvement in $\mathrm{HbA}_{1 \mathrm{c}}$ after supervised or unsupervised physical activity $[18,19]$, while other studies showed no benefit [20]. The possible explanation of the lack of improvement in glycemic control may be increased energy consumption and reduced insulin dose associated with increased activity, and, very likely, lack of incorporation of exercise into a structured lifestyle modification plan, introduced along with relevant patient education [18]. The influence of physical activity on glycemic control may also depend on the form of exercise training. The results of a recent meta-analysis demonstrate that only regular aerobic exercise training programs significantly improved acute and chronic glycemic control [21]. Interestingly, addition of brief bouts of high-intensity exercise to aerobic exercise may decrease the risk of late hypoglycemic episodes occurring after training [21]. In the studies that demonstrated a positive effect of exercise on glycemic control the decrease in $\mathrm{HbA}_{1 c}$ was not associated with a significant increase in episodes of hypoglycemia. Decreased insulin requirement is commonly associated with increased physical activity and may be explained mainly by increased insulin-independent glucose 
uptake by myocytes and increased peripheral insulin sensitivity [22]. Physical activity is effective in treatment of dyslipidemia in the general population [23]. The majority of studies in subjects with T1DM support the beneficial effect of physical exercise on lipid levels, which is similar to the nondiabetic population and independent of glycemia and weight reduction. In subjects with T1DM, physical activity is particularly effective in increasing the serum high-density lipoprotein (HDL)-cholesterol concentration, but it also significantly decreased low-density lipoprotein (LDL)-cholesterol and triglycerides [24-26]. Physical activity was also found to reduce the apolipoprotein B concentration and increase the protective apolipoprotein A1 in patients with T1DM [20].

There is limited evidence on the beneficial effect of physical exercise on blood pressure specifically in patients with T1DM. Some studies showed a small (<5\%) improvement [27] and other not [28], possibly due to insufficient power to detect a difference in a small sample of young, predominantly normotensive patients.

The effect of physical activity on the hard endpoints in the course of T1DM appears to be beneficial. The Pittsburgh IDDM (insulin-dependent diabetes mellitus) Morbidity and Mortality Study showed that male patients who had practiced team sports in their teens had decreased risk of macroangiopathy and all-cause mortality 25 years after diagnosis than those less physically active [29]. In women from this study the practice of team sports was nearly 2 times lower than in men, which might result in insufficient power to detect the benefit. The favorable effect on survival remained during 7-year follow-up of this group; however, again only in men, among whom sedentary subjects (overall activity level less than $1000 \mathrm{kcal} /$ week) had three times increased mortality when compared with active males (above $2000 \mathrm{kcal} /$ week) [15]. The same study provided evidence of a protective effect of physical activity on the development of diabetic nephropathy and neuropathy in men. The main weakness of this large study was its retrospective cohort design and subjective assessment of past physical activity. In the FinnDiane study presence of chronic complications was associated with reduced physical activity [30]. This may be largely because of the exercise-limiting effect of chronic complications, but the lower degree of albuminuria in patients reporting physical activity seems to be a causal relationship. Physical activity may also have a favorable effect on cardiovascular autonomic regulation in patients with T1DM, increasing heart rate variability [31], spontaneous baroreflex gain and low-frequency oscillation in arterial pressure [32].
Physical exercise increases insulin sensitivity in patients with T1DM [33], which may have an impact on the course of the disease. Insulin resistance is common in T1DM and associated with increased risk of its chronic complications [34]. In patients with diabetes physical activity may decrease oxidative stress [35] and reverse endothelial dysfunction $[36,37]$, and these effects may also contribute to the increased insulin sensitivity. Available evidence suggests the positive effect of physical activity on $\beta$-cell function in patients with T2DM [38] and overweight nondiabetic subjects [39], but it was not directly investigated in patients with T1DM. Physical activity also improves quality of life (QOL) and well-being in patients with T1DM, a condition generally associated with lower QOL and increased prevalence of depression [40].

Professional practice of competitive sports may have a different effect on health than leisure physical activity. Competitive sports are safe for people with T1DM if they have good metabolic control and are well educated about their disease and its interaction with physical exercise. However, aiming to improve performance and to achieve competitive success, some subjects may be involved in unhealthy practices that also have an adverse effect on metabolic control of diabetes [41]. These practices may include specific dietary patterns with excessive intake of single macronutrients, e.g. protein, use of nutritional supplements or illegal substances. Particular vigilance for early identification of disordered eating is needed in women with T1DM practicing esthetic disciplines and some endurance sports, including distance running or swimming, which are associated with increased risk of these disorders [41]. Some athletes with T1DM who practice sports with weight categories may omit insulin doses prior to weighing, which results in marked hyperglycemia, osmotic diuresis and rapid weight loss.

\section{Nutrition}

Nutrition seems to modulate the course of T1DM from its early preclinical stages. Absence or short duration of breastfeeding and early introduction of cow's milk formulae are thought to be risk factors for the disease [42]. Also rapid weight gain in infancy, associated with improper feeding, increases the risk of developing T1DM [43]. Analyzing the influence of diet as a lifestyle component on the course of T1DM, several aspects of nutrition may be taken into account, including macro- and micronutrient content, daily meal regimen, effect of food on glycemia and other metabolic parameters, and adjustment of insulin treatment to the timing and content of meals.

According to the current treatment approach, the diet recommended to patients with T1DM in 
general does not differ from a healthy diet suggested for the general population. This enables individualized dietary advice that interferes little with a patient's lifestyle. The restrictions on consistent day-to-day carbohydrate content of the meals might be an important consideration where premixed insulin or fixed basal-bolus treatment is used. In these treatment regimens day-to-day variations of carbohydrate content were associated with elevated $\mathrm{HbA}_{1 \mathrm{c}}$ level [44]. Patients who adjust insulin doses to the carbohydrate content of the meals do not need such restrictions to achieve adequate control of glycemia [45]. The Dose Adjustment for Normal Eating (DAFNE) trial examined the value of flexible intensive insulin treatment with dietary freedom and carbohydrate counting, accompanied by a structured education program based on principles developed by a team from Dusseldorf [46]. In the intervention group of this trial, not only a significant decrease in $\mathrm{HbA}_{1 c}$ value, but also better QOL, general wellbeing and treatment satisfaction were noted compared with the control group subjects, who started learning the method 6 months later [47]. Contrarily to the major concern of the DCCT, intensified treatment in the DAFNE trial did not increase the prevalence of hypoglycemia.

According to the above evidence, flexible meal pattern and content do not have a negative impact on the course and outcomes of T1DM in an educated patient using the appropriate treatment regimen. However, some diet choices may have a negative effect on parameters of metabolic control of the disease and, as a consequence, may result in increased risk of complications. These improper dietary habits include especially frequent consumption of food and beverages with a high glycemic index (GI) or diet low in carbohydrates and rich in saturated fat. Despite the fact that products with a high glycemic index are not strictly forbidden for patients with T1DM, especially those using flexible intensive insulin treatment, a rapid rise of postprandial glycemia following these meals is difficult to control even using rapid acting insulin analogues. Patients with T1DM who often consume meals with a high GI have poorly controlled postprandial glycemia, increased $\mathrm{HbA}_{1 \mathrm{c}}$ value, and decreased serum HDL-cholesterol concentration [48]. Frequent intake of high-Gl snacks, especially by children and adolescents, leads to obesity, dyslipidemia and poor glycemic control [49-51]. Interestingly, frequent consumption of diet beverages is associated with poor metabolic control of T1DM similarly to consumption of sweetened beverages, possibly being a marker of an unhealthy diet pattern [49]. An adverse effect of a high-GI diet on the atherogenic risk profile is a significant finding in patients with T1DM, as atherosclerotic cardiovascular diseases are a major cause of increased mortality in this group. On the other hand, patients must be advised not to increase the saturated fat intake when introducing the low-Gl diet. This was one of the causes of increased fat intake in the DCCT cohort. In the intensively treated patients of this trial, saturated fat equaled nearly $13 \%$ of total caloric intake and diets higher in total and saturated fat and lower in carbohydrate were associated with worse glycemic control independent of exercise and body mass index (BMI) [52]. The other cause of increased fat intake in some patients with T1DM may be low-carbohydrate nutrition used in an effort to minimize the need for insulin injections or to lose weight. As a consequence, people with T1DM consume a diet with higher fat and saturated fat content than recommended and even higher than members of the general population $[53,54]$. Meanwhile, carbohydrate intake may be partially substituted with sources of monounsaturated fat, which would reduce the glycemic index of the diet without an atherogenic effect [55].

Many young people with T1DM present a lifestyle associated with low attention to dietary choices and frequent consumption of fast food. Apart from other negative effects, this diet is usually associated with very high intake of food rich in trans-unsaturated fatty acids (from hydrogenated vegetable oils) and food additives, such as monosodium glutamate. Dietary trans fatty acids are associated with adverse cardiometabolic effects: increased low-grade inflammation, insulin resistance and accelerated atherosclerosis [56].

Consumption of sodium glutamate was associated with development of insulin resistance, T2DM and liver steatosis in animal models [57], but these effects were not investigated in humans. Consumption of a high purine diet or diet rich in fructose or sucrose contributes to hyperuricemia, which may play a pathogenic role in the metabolic syndrome and increase cardiovascular risk [58, 59]. Hyperuricemia may be associated with microvascular endothelial dysfunction in T1DM [60] and diabetic nephropathy [58].

Vitamins, including antioxidant $\mathrm{E}$ and $\mathrm{C}$, and mineral supplements are not routinely recommended in T1DM [61] but their use among patients is very common [62]. The evidence on the supplementation of vitamin D in T1DM is also insufficient, despite its possible favorable effects on oxidative stress, insulin resistance and autoimmunity [63].

Eating disorders are more common in T1DM than in the nondiabetic population [64]. While they are not lifestyles but clinical entities, behaviors not satisfying diagnostic criteria of a particular eating disorder are also common in T1DM [65]. Disor- 
dered eating is associated with poor compliance and metabolic control and decreased survival in T1DM [66] with increased risk of both DKA and chronic complications of the disease. Binge eating disorder was found to be associated with the practice of insulin omission in women with T1DM [67].

\section{Alcohol and illicit drugs intake}

In patients with T1DM alcohol consumption may cause hypoglycemia mainly due to gluconeogenesis inhibition. Alcohol intake may also result in neglecting diabetes self-care - not measuring glycemia, omitting insulin doses and also involvement in risky behavior $[68,69]$. These have an adverse influence on metabolic control and the course of disease, including glycemic instability and increased risk of DKA [70]. It is worth noting that moderate consumption of wine is not prohibited, and may have beneficial vascular effects in diabetes [71].

The data on illicit drug use among patients with T1DM are sparse, but the clinical observations confirm its deleterious effect on the course of the disease, severely compromising the patient's selfcare practices [72].

\section{Smoking}

Cigarette smoking adversely influences health, and the risk increases considerably when added to the risk conferred by diabetes. During 6-year observation of a T1DM cohort, Moy et al. [73] reported over 2.5 times increased risk of death in female smokers compared with nonsmokers, which was explained mainly by increased cardiovascular mortality. Hormonal responses to cigarette smoking, including growth hormone, cortisol and vasopressin, are counter-regulatory to insulin [74] and may lead to insulin resistance [75]. Nicotine may also directly inhibit insulin secretion [76]. Patients with T1DM who smoke were found to have higher $\mathrm{HbA}_{1 c}$ values than non-smoking subjects [77] and experience shorter partial remission [78]. Moreover, diabetic patients who smoke report less confidence in health care professionals, are more likely to report symptoms of depression, and may be less compliant to treatment [79]. Apart from accelerated atherosclerosis [80], smoking is associated with increased risk of microangiopathic complications in T1DM. This relationship is well documented for diabetic nephropathy and neuropathy, and very likely for retinopathy. Sawicki et al. [81] reported that over 1 year of observation, progression of nephropathy was less common in nonsmokers $(11 \%)$ than in smokers $(53 \%)$ and in past smokers (33\%). In another study [82] during 6 -year observation, the odds of progression of nephropathy increased by $27 \%$ for each 10 pack years. In a study by Mitchell et al. [83] patients smoking 30 pack years or more were 3.32 times more likely to have neuropathy than those smoking less than this amount.

\section{Psychological stress}

Stressful life events, such as losses within the family, were found to be associated with increased risk of development of T1DM in children, especially in the age group of 5-9 years [84], but also older ones [85]. These events occurred mainly during the second year preceding the diagnosis of T1DM and may be considered as possible triggering factors that precipitate or accelerate the autoimmune process. In patients with established T1DM, psychological stress may be associated with poor glycemic control [86]. The causality of this relationship is supported by a study in which acute psychosocial stress was associated with subsequent hyperglycemia [87]. Of note, marked individual differences occur in the blood glucose response to stress, and in many subjects the reactivity may be weak or undetectable [88].

\section{Sleep duration}

The influence of sleep duration on glycemic control of T1DM is unknown. However, partial sleep restriction decreased glucose tolerance in healthy subjects [89] and induced insulin resistance in both healthy subjects [90] and in patients with T1DM [91]. In patients with T1DM short sleep duration may also be associated with the blood pressure nondipping pattern [92]. Patients with a long history of T1DM have poor subjective sleep quality and are at increased risk for obstructive sleep apnea [93] compared with nondiabetic controls. Sleep-disordered breathing is associated with poor metabolic control and decreased quality of life [94].

\section{Socioeconomic status}

The association between socioeconomic status and the course of T1DM was analyzed in the Pittsburgh Epidemiology of Diabetes Complication Study. Lower education was associated with increased prevalence of end-stage renal disease and coronary artery disease, and lower income was associated with autonomic neuropathy and peripheral arterial disease [95]. Higher educational level was also found to be associated with lower mortality in T1DM [96]. These associations, although independent of sex and diabetes duration, may be partly mediated by poorer management of diabetes and presence of risk factors for chronic complications. Lower family income was associated with worse glycemic control in adult and adolescent patients with T1DM [97]. On the other 
hand, higher socioeconomic status and higher degree of urbanization are associated with increased incidence and prevalence of T1DM [98].

\section{Conclusions}

Although lifestyle seems to modify the course of T1DM in many ways, the evidence on these relationships appears to be very incomplete. The largest body of evidence was accumulated on the influence of nutrition, physical activity and smoking on diabetes-related outcomes; however, many questions remain, including those already answered for T2DM. Other lifestyle parameters have rarely been analyzed in patients with T1DM.

This necessitates further research, especially including the assessment of the efficacy of lifestyle interventions on the course of T1DM.

\section{References}

1. Atkinson MA. ADA Outstanding Scientific Achievement Lecture 2004. Thirty years of investigating the autoimmune basis for type 1 diabetes: why can't we prevent or reverse this disease? Diabetes 2005; 54: 1253-63.

2. Wilkin TJ. The accelerator hypothesis: weight gain as the missing link between type I and type II diabetes. Diabetologia 2001; 44: 914-22.

3. Dabelea D, Mayer-Davis EJ, Andrews JS, et al. Clinical evolution of beta cell function in youth with diabetes: the SEARCH for Diabetes in Youth study. Diabetologia 2012; 55: 3359-68.

4. Merger SR, Leslie RD, Boehm BO. The broad clinical phenotype of type 1 diabetes at presentation. Diabet Med 2012; 30: 170-8.

5. Steffes MW, Sibley S, Jackson M, Thomas W. Beta-cell function and the development of diabetes-related complications in the diabetes control and complications trial. Diabetes Care 2003; 26: 832-6.

6. Sustained effect of intensive treatment of type 1 diabetes mellitus on development and progression of diabetic nephropathy: the Epidemiology of Diabetes Interventions and Complications (EDIC) study. JAMA 2003; 290: 2159-67.

7. Rogowicz-Frontczak A, Araszkiewicz A, Pilacinski S, Zozulinska-Ziolkiewicz D, Wykretowicz A, Wierusz-Wysocka B. Carotid intima-media thickness and arterial stiffness in type 1 diabetic patients with and without microangiopathy. Arch Med Sci 2012; 8: 484-90.

8. Groop PH, Thomas MC, Moran JL, et al. The presence and severity of chronic kidney disease predicts allcause mortality in type 1 diabetes. Diabetes 2009; 58: 1651-8.

9. Okruszko A, Szepietowska B, Wawrusiewicz-Kurylonek N, Gorska M, Kretowski A, Szelachowska M. HLA-DR, HLADQB1 and PTPN22 gene polymorphism: association with age at onset for autoimmune diabetes. Arch Med Sci 2012; 8: 874-8.

10. Alvin W. Thesaurus of psychological index terms. 8 edn. American Psychological Association 1997.

11. Health Promotion Glossary World Health Organization 1998; 26 http://www.who.int/healthpromotion/about/ HPR Glossary 1998.pdf (accessed:08.03.2013)

12. Writing Team for the Diabetes Control and Complications Trial/Epidemiology of Diabetes Interventions and
Complications Research Group. Effect of intensive therapy on the microvascular complications of type 1 diabetes mellitus. JAMA 2002; 287: 2563-9.

13. Department of Health, Physical Activity, Health Improvement and Prevention. The benefits of physical activity for adult health. At least five a week. Evidence on the impact of physical activity and its relationship to health. A report from the Chief Medical Officer. London: Department of Health 2004; 38-64.

14. Chimen M, Kennedy A, Nirantharakumar K, Pang TT, Andrews R, Narendran P. What are the health benefits of physical activity in type 1 diabetes mellitus? A literature review. Diabetologia 2012; 55: 542-51.

15. Moy CS, Songer TJ, LaPorte RE, et al. Insulin-dependent diabetes mellitus, physical activity, and death. Am J Epidemiol 1993; 137: 74-81.

16. Galler A, Lindau M, Ernert A, Thalemann R, Raile K. Associations between media consumption habits, physical activity, socioeconomic status, and glycemic control in children, adolescents, and young adults with type 1 diabetes. Diabetes Care 2011; 34: 2356-9.

17. Thomas DE, Elliott EJ, Naughton GA. Exercise for type 2 diabetes mellitus. Cochrane Database Syst Rev 2006; 3: CD002968.

18. Zinman B, Zuniga-Guajardo S, Kelly D. Comparison of the acute and long-term effects of exercise on glucose control in type I diabetes. Diabetes Care 1984; 7: 515-9.

19. Durak EP, Jovanovic-Peterson L, Peterson CM. Randomized crossover study of effect of resistance training on glycemic control, muscular strength, and cholesterol in type I diabetic men. Diabetes Care 1990; 13: 1039-43.

20. Laaksonen DE, Atalay M, Niskanen LK, et al. Aerobic exercise and the lipid profile in type 1 diabetic men: a randomized controlled trial. Medicine and Science in Sports and Exercise 2000; 32: 1541-8.

21. Tonoli C, Heyman E, Roelands B, et al. Effects of different types of acute and chronic (training) exercise on glycaemic control in type 1 diabetes mellitus: a meta-analysis. Sports Med 2012; 42: 1059-80.

22. Langfort J, Viese M, Ploug T, Dela F. Time course of GLUT4 and AMPK protein expression in human skeletal muscle during one month of physical training. Scand J Med Sci Sports 2003; 13: 169-74.

23. Barylski M, Malyszko J, Rysz J, Mysliwiec M, Banach M. Lipids, blood pressure, kidney - what was new in 2011 ? Arch Med Sci 2012; 7: 1055-66.

24. Williamson DA, Rejeski J, Lang W, Van Dorsten B, Fabricatore AN, Toledo K. Impact of a weight management program on health-related quality of life in overweight adults with type 2 diabetes. Arch Intern Med 2009; 169: 163-71.

25. Rigla M, Sanchez-Quesada JL, Ordonez-Llanos J, et al. Effect of physical exercise on lipoprotein(a) and low-density lipoprotein modifications in type 1 and type 2 diabetic patients. Metabol Clin Exp 2000; 49: 640-7.

26. Mosher PE, Nash MS, Perry AC, LaPerriere AR, Goldberg RB. Aerobic circuit exercise training: effect on adolescents with well-controlled insulin-dependent diabetes mellitus. Arch Phys Med Rehabil 1998; 79: 652-7.

27. Lehmann R, Kaplan V, Bingisser R, Bloch KE, Spinas GA. Impact of physical activity on cardiovascular risk factors in IDDM. Diabetes Care 1997; 20: 1603-11.

28. Fuchsjager-Mayrl G, Pleiner J, Wiesinger GF, et al. Exercise training improves vascular endothelial function in patients with type 1 diabetes. Diabetes Care 2002; 25: 1795-801.

29. LaPorte RE, Dorman JS, Tajima N. Pittsburgh insulin-dependent diabetes mellitus morbidity and mortality 
study: Physical activity and diabetic complications. Pediatrics 1986; 78: 1027-33.

30. Waden J, Forsblom C, Thorn LM, et al. Physical activity and diabetes complications in patients with type 1 diabetes: the finnish diabetic nephropathy (FinnDiane) study. Diabetes Care 2008; 31: 230-2.

31. Chen SR, Lee YJ, Chiu HW, Jeng C. Impact of physical activity on heart rate variability in children with type 1 diabetes. Childs Nerv Syst 2008; 24: 741-7.

32. Lucini D, Zuccotti GV, Scaramuzza A, Malacarne M, Gervasi F, Pagani M. Exercise might improve cardiovascular autonomic regulation in adolescents with type 1 diabetes. Acta Diabetol 2013; 50: 341-9.

33. Yki-Jarvinen H, DeFronzo RA, Koivisto VA. Normalization of insulin sensitivity in type I diabetic subjects by physical training during insulin pump therapy. Diabetes Care 1984; 7: 520-7.

34. Chaturvedi N, Sjoelie AK, Porta M, et al. Markers of insulin resistance are strong risk factors, for retinopathy incidence in type 1 diabetes: the EURODIAB prospective complications study. Diabetes Care 2001; 24: 284-9.

35. Kurban S, Mehmetoglu I, Yerlikaya HF, Gonen S, Erdem S. Effect of chronic regular exercise on serum ischemia-modified albumin levels and oxidative stress in type 2 diabetes mellitus. Endocr Res 2011; 36: 116-23.

36. Seeger JP, Thijssen DH, Noordam K, Cranen ME, Hopman MT, Nijhuis-van der Sanden MW. Exercise training improves physical fitness and vascular function in children with type 1 diabetes. Diabetes Obes Metab 2011; 13: 382-4.

37. Fuchsjager-Mayrl G, Pleiner J, Wiesinger GF, et al. Exercise training improves vascular endothelial function in patients with type 1 diabetes. Diabetes Care 2002; 25 1795-801.

38. Dela F, von Linstow ME, Mikines KJ, Galbo H. Physical training may enhance beta-cell function in type 2 diabetes. Am J Physiol Endocrinol Metab 2004; 287: E1024-31.

39. Slentz CA, Tanner CJ, Bateman LA, et al. Effects of exercise training intensity on pancreatic beta-cell function. Diabetes Care 2009; 32: 1807-11.

40. Zoppini G, Carlini M, Muggeo M. Self-reported exercise and quality of life in young type 1 diabetic subjects. Diabetes Nutr Metabol 2003; 16:77-80.

41. Hornsby Jr WG, Chetlin RD. Management of competitive athletes with diabetes. Diabetes Spectrum 2005; 18 : 102-7.

42. Atkinson MA, Ellis TM. Infants diets and insulin-dependent diabetes: evaluating the "cows' milk hypothesis" and a role for anti-bovine serum albumin immunity. J Am Coll Nutr 1997; 16: 334-40.

43. Hypponen E, Kenward MG, Virtanen SM, et al. Infant feeding, early weight gain, and risk of type 1 diabetes. Childhood Diabetes in Finland (DiMe) Study Group. Diabetes Care 1999; 22: 1961-5.

44. Wolever TM, Hamad S, Chiasson JL, et al. Day-to-day consistency in amount and source of carbohydrate intake associated with improved blood glucose control in type 1 diabetes. J Am Coll Nutr 1999; 18: 242-7.

45. Rabasa-Lhoret R, Garon J, Langelier H, Poisson D, Chiasson JL. Effects of meal carbohydrate content on insulin requirements in type 1 diabetic patients treated intensively with the basal-bolus (ultralente-regular) insulin regimen. Diabetes Care 1999; 22: 667-73.

46. Muhlhauser I, Jorgens V, Berger M, et al. Bicentric evaluation of a teaching and treatment programme for type 1 (insulin-dependent) diabetic patients: improvement of metabolic control and other measures of dia- betes care for up to 22 months. Diabetologia 1983; 25: 470-6

47. DAFNE Study Group. Training in flexible, intensive insulin management to enable dietary freedom in peo ple with type 1 diabetes: dose adjustment for normal eating (DAFNE) randomised controlled trial. BMJ 2002; 325: 746.

48. Buyken AE, Toeller M, Heitkamp G, et al. Glycemic index in the diet of European outpatients with type 1 diabe tes: relations to glycated hemoglobin and serum lipids. Am J Clin Nutr 2001; 73: 574-81.

49. Bortsov AV, Liese AD, Bell RA, et al. Sugar-sweetened and diet beverage consumption is associated with cardiovascular risk factor profile in youth with type 1 diabetes. Acta Diabetol 2011; 48: 275-82.

50. Nansel TR, Haynie DL, Lipsky LM, Laffel LM, Mehta SN. Multiple indicators of poor diet quality in children and adolescents with type 1 diabetes are associated with higher body mass index percentile but not glycemic control. J Acad Nutr Diet 2012; 112: 1728-35.

51. Kyriazis I, Rekleiti M, Saridi M, et al. Prevalence of obesity in children aged 6-12 years in Greece: nutritional behaviour and physical activity. Arch Med Sci 2012; 8 : 859-64.

52. Delahanty LM, Nathan DM, Lachin JM, et al. Association of diet with glycated hemoglobin during intensive treatment of type 1 diabetes in the Diabetes Control and Complications Trial. Am J Clin Nutr 2009; 89: 518-24.

53. Snell-Bergeon JK, Chartier-Logan C, Maahs DM, et al. Adults with type 1 diabetes eat a high-fat atherogenic diet that is associated with coronary artery calcium. Diabetologia 2009; 52: 801-9.

54. Overby NC, Flaaten V, Veierod MB, et al. Children and adolescents with type 1 diabetes eat a more atherosclerosis-prone diet than healthy control subjects. Diabetologia 2007; 50: 307-16.

55. Strychar I, Cohn JS, Renier G, et al. Effects of a diet higher in carbohydrate/lower in fat versus lower in carbohydrate/higher in monounsaturated fat on postmea triglyceride concentrations and other cardiovascular risk factors in type 1 diabetes. Diabetes Care 2009; 32: 1597-9.

56. Micha R, Mozaffarian D. Trans fatty acids: effects on metabolic syndrome, heart disease and diabetes. Nat Rev Endocrinol 2009; 5: 335-44.

57. Sasaki Y, Suzuki W, Shimada T, et al. Dose dependent development of diabetes mellitus and non-alcoholic steatohepatitis in monosodium glutamate-induced obese mice. Life Sci 2009; 85: 490-8.

58. Hovind P, Rossing P, Johnson RJ, Parving HH. Serum uric acid as a new player in the development of diabetic nephropathy. J Ren Nutr 2011; 21: 124-7.

59. Katsiki N, Karagiannis A, Athyros VG, Mikhailidis DP. Hyperuricaemia: more than just a cause of gout? J Cardiovasc Med (Hagerstown) 2013; 14: 397-402.

60. Matheus AS, Tibirica E, da Silva PB, de Fatima Bevilac qua da Matta M, Gomes MB. Uric acid levels are asso ciated with microvascular endothelial dysfunction in patients with type 1 diabetes. Diabet Med 2011; 28: 1188-93.

61. Standards of medical care in diabetes-2013. Diabetes Care 2013; 36 Suppl. 1: S11-66.

62. Lemay JF, Amin A, Pacaud D. Complementary and alternative medicine use in children and adolescents with type 1 diabetes. Paediatr Child Health 2012; 16: 468-72.

63. George PS, Pearson ER, Witham MD. Effect of vitamin D supplementation on glycaemic control and insulin re- 
sistance: a systematic review and meta-analysis. Diabet Med 2012; 29: e142-50.

64. Goebel-Fabbri AE. Disturbed eating behaviors and eating disorders in type 1 diabetes: clinical significance and treatment recommendations. Curr Diab Rep 2009; 9: 133-9.

65. Tse J, Nansel TR, Haynie DL, Mehta SN, Laffel LM. Disordered eating behaviors are associated with poorer diet quality in adolescents with type 1 diabetes. J Acad Nutr Diet 2012; 112: 1810-4.

66. Neumark-Sztainer D, Patterson J, Mellin A, et al. Weight control practices and disordered eating behaviors among adolescent females and males with type 1 diabetes: associations with sociodemographics, weight concerns, familial factors, and metabolic outcomes. Di abetes Care 2002; 25: 1289-96.

67. Takii M, Komaki G, Uchigata Y, Maeda M, Omori Y, Kubo C. Differences between bulimia nervosa and binge-eating disorder in females with type 1 diabetes: the important role of insulin omission. J Psychosom Res 1999; 47: 221-31.

68. Scaramuzza A, De Palma A, Mameli C, Spiri D, Santoro L, Zuccotti GV. Adolescents with type 1 diabetes and risky behaviour. Acta Paediatr 2010; 99: 1237-41.

69. Ahmed AT, Karter AJ, Liu J. Alcohol consumption is inversely associated with adherence to diabetes self-care behaviours. Diabet Med 2006; 23: 795-802.

70. Ismail D, Gebert R, Vuillermin PJ, et al. Social consump tion of alcohol in adolescents with type 1 diabetes is associated with increased glucose lability, but not hypoglycaemia. Diabet Med 2006; 23: 830-3.

71. Caimi G, Carollo C, Lo Presti R. Diabetes mellitus: oxidative stress and wine. Curr Med Res Opin 2003; 19 581-6.

72. Hanna KM, Guthrie DW. Health-compromising behavior and diabetes mismanagement among adolescents and young adults with diabetes. Diabetes Educ 2001; 27 223-30.

73. Moy CS, LaPorte RE, Dorman JS, et al. Insulin-dependent diabetes mellitus mortality. The risk of cigarette smok ing. Circulation 1990; 82: 37-43.

74. Chiodera P, Volpi R, Capretti L, et al. Abnormal effect of cigarette smoking on pituitary hormone secretions in insulin-dependent diabetes mellitus. Clin Endocrinol (Oxf) 1997; 46: 351-7.

75. Seet RC, Loke WM, Khoo CM, et al. Acute effects of cig arette smoking on insulin resistance and arterial stiffness in young adults. Atherosclerosis 2012; 224: 195-200.

76. Yoshikawa H, Hellstrom-Lindahl E, Grill V. Evidence for functional nicotinic receptors on pancreatic beta cells Metabolism 2005; 54: 247-54.

77. Nilsson PM, Gudbjornsdottir S, Eliasson B, Cederholm J. Smoking is associated with increased $\mathrm{HbA1c}$ values and microalbuminuria in patients with diabetes: data from the National Diabetes Register in Sweden. Diabetes Metab 2004; 30: 261-8.

78. Pilacinski S, Adler Al, Zozulinska-Ziolkiewicz DA, Gaw recki $A$, Wierusz-Wysocka $B$. Smoking and other factors associated with short-term partial remission of type 1 diabetes in adults. Diabet Med 2012; 29: 464-9.

79. Haire-Joshu D, Heady S, Thomas L, Schechtman K, Fisher EB Jr. Depressive symptomatology and smoking among persons with diabetes. Res Nurs Health 1994; 17: 273-82.

80. Polak JF, Backlund JY, Cleary PA, et al. Progression of carotid artery intima-media thickness during 12 years in the Diabetes Control and Complications Trial/Epide- miology of Diabetes Interventions and Complications (DCCT/EDIC) study. Diabetes 2011; 60: 607-13.

81. Sawicki PT, Didjurgeit U, Muhlhauser I, Bender R, Heinemann L, Berger M. Smoking is associated with progression of diabetic nephropathy. Diabetes Care 1994; 17: 126-31.

82. Muhlhauser I, Bender R, Bott U, et al. Cigarette smoking and progression of retinopathy and nephropathy in type 1 diabetes. Diabet Med 1996; 13: 536-43.

83. Mitchell BD, Hawthorne VM, Vinik Al. Cigarette smoking and neuropathy in diabetic patients. Diabetes Care 1990; 13: 434-7.

84. Hagglof B, Blom L, Dahlquist G, Lonnberg G, Sahlin B. The Swedish childhood diabetes study: indications of severe psychological stress as a risk factor for type 1 (insulin-dependent) diabetes mellitus in childhood. Diabetologia 1991; 34: 579-83.

85. Karavanaki K, Tsoka E, Liacopoulou M, et al. Psychological stress as a factor potentially contributing to the pathogenesis of type 1 diabetes mellitus. J Endocrinol Invest 2008; 31: 406-15.

86. Lloyd CE, Dyer PH, Lancashire RJ, Harris T, Daniels JE, Barnett $\mathrm{AH}$. Association between stress and glycemic control in adults with type 1 (insulin-dependent) diabetes. Diabetes Care 1999; 22: 1278-83.

87. Wiesli P, Schmid C, Kerwer O, et al. Acute psychological stress affects glucose concentrations in patients with type 1 diabetes following food intake but not in the fasting state. Diabetes Care 2005; 28: 1910-5.

88. Riazi A, Pickup J, Bradley C. Daily stress and glycaemic control in type 1 diabetes: individual differences in magnitude, direction, and timing of stress-reactivity. Diabetes Res Clin Pract 2004; 66: 237-44.

89. Nedeltcheva AV, Kessler L, Imperial J, Penev PD. Exposure to recurrent sleep restriction in the setting of high caloric intake and physical inactivity results in increased insulin resistance and reduced glucose tolerance. J Clin Endocrinol Metab 2009; 94: 3242-50.

90. Donga E, van Dijk M, van Dijk JG, et al. A single night of partial sleep deprivation induces insulin resistance in multiple metabolic pathways in healthy subjects. J Clin Endocrinol Metab 2010; 95: 2963-8.

91. Donga E, van Dijk M, van Dijk JG, et al. Partial sleep restriction decreases insulin sensitivity in type 1 diabetes. Diabetes Care 2010; 33: 1573-7.

92. Borel AL, Benhamou PY, Baguet JP, et al. Short sleep duration is associated with a blood pressure nondipping pattern in type 1 diabetes: the DIAPASOM study. Diabetes Care 2009; 32: 1713-5.

93. van Dijk M, Donga E, van Dijk JG, et al. Disturbed subjective sleep characteristics in adult patients with long-standing type 1 diabetes mellitus. Diabetologia 2011; 54: 1967-76.

94. Perfect MM, Patel PG, Scott RE, et al. Sleep, glucose, and daytime functioning in youth with type 1 diabetes. Sleep 2012; 35: 81-8.

95. Secrest AM, Costacou T, Gutelius B, Miller RG, Songer TJ, Orchard TJ. Associations between socioeconomic status and major complications in type 1 diabetes: the Pittsburgh epidemiology of diabetes complication (EDC) Study. Ann Epidemiol 2011; 21: 374-81.

96. Secrest AM, Becker DJ, Kelsey SF, Laporte RE, Orchard TJ. Cause-specific mortality trends in a large population-based cohort with long-standing childhood-onset type 1 diabetes. Diabetes 2010; 59: 3216-22

97. Zgibor JC, Songer TJ, Kelsey SF, et al. The association of diabetes specialist care with health care practices 
and glycemic control in patients with type 1 diabetes: a cross-sectional analysis from the Pittsburgh epidemiology of diabetes complications study. Diabetes Care 2000; 23: 472-6.

98. Liese AD, Puett RC, Lamichhane AP, et al. Neighborhood level risk factors for type 1 diabetes in youth: the SEARCH case-control study. Int J Health Geogr 2012; 11: 1. 